\title{
An Analysis of the Issues and Prospects facing SriLankan Airlines and its embedded partnership with Sri Lankan Tourism.
}

\author{
Lasitha Nagahawatte \\ Saffron Aviation (Pvt) Ltd. No. 11, York Street, Colombo 1, Sri Lanka
}

John F. O'Connell

Centre for Air Transport Management, Martell House, Bedfordshire, MK43 OTR, England. E-mail: frankie.oconnell@cranfield.ac.uk(corresponding author)

The long civil war, which ended in May 2009, combined with the poor economic performance and weak travel demand to Sri Lanka all coalesced in hindering the tourism industry. Consequently its aviation industry, which is dominated by the national carrier SriLankan Airlines, faced growing and difficult challenges. However since 2009 the country has witnessed a boom in tourism, while an unprofitable SriLankan Airlines changed its financial and strategic circumstances by becoming a member of the Oneworld alliance in Mid-2014, driven by its regional geography and proximity to India which had strict bilateral traffic rights for international incumbents from the UK and the UAE. This study analyses tourism, economic, and passenger data combined with results from a passenger survey and expert interviews in order to identify the critical issues and future prospects of aviation and tourism in Sri Lanka. This paper concludes that its ageing long haul fleet together with an inferior economy-class product along with high fuel prices, capacity constraints, and poor management practices as the major issues faced by SriLankan Airlines. On the tourism side; uncompetitive hotel rates, unnecessarily high government taxes, visa charges and the lack of international promotion was seen as the principle drawbacks. A survey at Colombo airport revealed that fare is 
the principle rhetoric for passengers taking SriLankan Airlines but choose foreign carriers due to their range of additional and superior attributes.

Keywords: Sri Lanka, SriLankan Airlines, Tourism, Oneworld

Sri Lanka, is located in the South of India, is famously known as the 'Pearl of the Indian Ocean' or the 'Emerald Isle'. Its citizens and rulers have faced many invasions over the years from its neighbours and the country was colonised by the Portuguese, Dutch and the British in succession. The island gained independence from the British in 1948 after the Second World War and ever since, has been a sovereign state. A major civil war which commenced in 1983 and lasted for 25 years stagnated the tourism industry. An insurgency group known as the 'Liberation Tigers of Tamil Eelam' (LTTE), fought against the residing Government to create an independent Tamil state in the north and the east of the island - an estimated 80,000-100,000 people were killed during its course (UNdata, 2014).

Sri Lanka has a population of 21.6 million, out of which only $15 \%$ (2011 data) is habituating in an urban environment (CIA, 2013). Sri Lanka is unitary state governed by a presidential system. It is divided into nine provinces and sub divided into 25 districts. As a culturally diverse nation, it is home to eight ethnicities, with Sinhalese (73.8\%) being the majority followed by Sri Lankan and Indian Tamils (8.5\%), and Sri Lankan Moors (7.2\%) (Department of Census and Statistics - Sri Lanka, 2012).

In 1985, free market economy was introduced by the government at that time, promoting privatisation, deregulation and the growth of private enterprises (Subasinghe, 1985). This promoted industrialisation and increased the importance of tea export, clothing exports, and other agricultural production together with the tourism industry (Ministry of Finance and Planning, 2013). By 2009, the civil war ended and the subsequent prevailing peaceful environment has had a positive impact on Tourism as it has become one of the country's most major industries, which has encountered an influx of tourists from all over the world due to the peaceful environment. 
Government owned SriLankan Airlines has played a major role in the post war economic growth of the nation and it made a major leap forward by becoming a full member of the Oneworld alliance in May 2014 after it passed through the rigorous processes and checks that the alliance mandates - a clear sign that the carrier is worthy of international standards.

Sri Lanka's tourism industry and national flag carrier is gradually transgressing to capture more traffic to the Island and has put in-place an infrastructure to deliver this increased capacity. However, issues and problems of varying importance and impacts continue to impact the growth of two industries in Sri Lanka. This study addresses such issues accordingly and investigates the future prospects of the tourism and aviation industries in Sri Lanka.

\section{Sri Lanka's Tourism Industry}

Sri Lanka projects itself as a vibrant and diverse tourist destination, with many offerings bundled into a holiday package that could be explored within a few days. According to the World Travel and Tourism Council Data (2013), tourism contributes 3.8\% to the Sri Lankan GDP - the Government aspires to grow Sri Lanka into a tourism centric nation. The Sri Lankan Tourism Development Authority (SLTDA, 2012) identifies seven popular tourist regions in the country and the major cities located in each region which are identified in Figure 1. Out of which, most parts of the Northern and the East Coast were out of bounds pre-2009, but since then, ongoing tourism capturing projects have been carried out to boost the attractiveness and improve the offerings in these regions (Wijedasa, 2014).

\section{[INSERT FIGURE 1 HERE]}

In terms of international tourist traffic, traditionally India, United Kingdom, Germany and Maldives have been the largest markets as shown in Figure 2. From the end of the civil war to 
2013, the growth of tourism traffic has encountered exponential growth rates as the United Kingdom for example has witnessed growth rates of $68 \%$, whereas India, Maldives and Germany has seen a growth of $150 \%, 149 \%$ and $189 \%$ respectively during the same period. More recently, Chinese travellers has seen a much rapid increase as there were 8,550 passengers in 2009, whereas within the first ten months of 2014 , the 100,000 Chinese nationals entered the country. The traffic surge from Western Europe could be attributable to the rapid growth of the Gulf carriers, providing effortless connections, with SriLankan Airlines adopting similar strategies in the South Asian and Chinese markets to capture growing demand (OAG, 2014).

\section{[INSERT FIGURE 2 HERE]}

The availability of tourist accommodation options is of prime importance in the tourism industry. There are over 1,500 tourist accommodation establishments in Sri Lanka to choose from, varying from up market five star hotels to lower grade guest houses as shown in Figure 3 (SLTDA, 2014b). Majority of the five and four star hotels are located in Colombo, Central, Western and Southern coastal regions. All other types of accommodation are located all throughout the popular tourist regions (Wijedasa, 2014).

[INSERT FIGURE 3 HERE]

\section{The changing trends in SriLankan aviation}

Sri Lanka is a relatively small aviation market, shadowed by neighbouring India, but is placed as the $15^{\text {th }}$ largest international market in the Asia-Pacific region (CAPA, 2014b). 
Rajapaksha (2005) claims that the government in its policy statements recognises aviation as one the key developments pillars in its economic prosperity. Perovic (2013) reported that aviation's contribution to the global GDP is estimated at 3.5\%, while SriLankan Airlines annual report (2013) has correlated this estimate, by stating that the carrier has contributed $2.2 \%$ to the national GDP of US\$65.1 billion while the country's GDP has seen a Y-o-Y growth of $7.2 \%$ between 2012 and 2013 with aviation at the forefront of this development (Department of Census and Statistics, Sri Lanka, 2014). Doganis (2010) establishes the importance of the direct interrelationship between GDP and air traffic demand, while Cassim (2013) argues that in the Asia Pacific region, air transport has a 13 times multiplier effect on the economy with a catalytic and direct impact on tourism and related industries.

SriLankan Airlines carried 4.27 million passengers with a load factor of $83.2 \%$ in 2013 , recovering rapidly from the dip in 2009 where it carried only 2.42 million passengers with a load factor of 75.6\% (ICAODATA+, 2014). Currently SriLankan Airlines accounts for 54\% of the market share at Colombo Airport, in terms of flight departures and ASKs (CAPA, 2014b). Between 2009 and 2014 SriLankan Airlines has grown from; 18 to 44 daily flights, 12 to 22 aircraft and the network from 27 to 32 destinations (OAG, 2014), moving into a more passive state. Its mission statement is to develop its international markets and boost the number of tourists visiting the island nation and its aspiration is 'To be the most preferred airline in Asia' (SriLankan Airlines, 2013).

The South Asian market is the airline's strong hold, with India being the single largest market as 80 flights are operated weekly to eight Indian cities, followed by Maldives, with more than 30 weekly flights, as the largest operator to the iconic holiday destination (OAG, 2014). Europe remains a key market for SriLankan Airlines but mounting competition by the incumbent Gulf carriers who are entrenched at their mega-hubs in Dubai, Abu Dhabi and Doha have negatively impacted the yields considerably forcing SriLankan Airlines to 
discourage adding any further European destinations - a major threat for the domiciled flag carrier (SriLankan Airlines, 2013). However the market dynamics have been changing over the past five years, as China has become one of the most important destinations for the airline. China has now become the largest trade partner of the island, surpassing the US, as ties between the two countries magnify (Ondaatjie, 2014). In 2013 alone, China has invested US\$3.69 billion out of the total US\$8.91 billion it had invested in Sri Lanka since 2006 (Heritage Foundation, 2014). In terms of trade, China in 2012 had accounted for $9.6 \%$ of Sri Lanka's total international trade compared to 5.2\% in 2008 (Ondaatjie, 2014). Currently SriLankan Airlines operates scheduled services to five destinations in China and have shown interest in tapping into more emerging Chinese markets. Beijing, Shanghai and Kunming is currently served directly, whereas Guangzhou and Hong Kong is served with a technical stop in Bangkok. However, Cassim (2013) reports that only one in ten passengers flying with SriLankan Airlines from China steps foot in Sri Lanka, with the rest disembarking in either India or the Maldives - showing the Hub connectivity potential that SriLankan Airlines has developed in its home base at Colombo Airport.

The airline operates an all Airbus fleet of 24 aircraft (as at 01/10/2014) with; A320-Family (10), A330-Family (8), A340-300 (6), with A330-300 (5) with 7 A350-900s on order. The aircraft on order are to replace the existing fleet stipulating that the total fleet will not grow beyond its present capacity. Operationally SriLankan Airlines' is on par with the world's leading carriers as benchmark analysis reveals that its daily aircraft utilisation exceeds that of industry leaders such as British Airways and India's Jet Airways as displayed in Table 1. Taking into account the average fleet age of 5.9 years for it's the short-haul fleet and 15.0 years for the long-haul fleet, the results are commendable. 
However the employee productivity is problematic for the Sri Lankan incumbent as the carrier is overstaffed with 289 employees per aircraft, compare to 134 for Singapore Airlines as shown in Table 2. Low staff cost has allowed SriLankan Airlines to maintain this bloated labour force but risks the potential of unrest and poor morale amongst the employees who are struggling financially. Wickramasinghe (2014) states that the principle reasons behind having such a large number of employees at relatively low costs are attributable to government efforts in providing employment, while there remains a lack of minimum wage restrictions within its socio-cultural landscape which precludes the carrier from offering escalated wages offerings.

\section{[INSERT TABLE 2 HERE]}

Financially, SriLankan Airlines continues to struggle, continuously generating losses. In 2013 alone it declared a net loss of $\$ 248$ million on revenues of just $\$ 932$ million (Flightglobal, 2014). Fuel costs, accounts for nearly $50 \%$ of the total operating costs of SriLankan Airlines, much higher when compared to the $30 \%$ global industry average (IATA, 2014). Heavy taxes and other levies charged on the imported fuel is the principle reason behind the high cost mechanism which is having a critical impact on its ability to deliver profits. In addition the declining yields coupled with the recession in Europe and severe competition are widening of the gap between revenues and costs. One of the most high profile events in SriLankan Airlines' history was its induction into the Oneworld alliance on 1-May-2014, becoming the first carrier from the Indian Subcontinent to join any global alliance (SriLankan.com, 2014). The airline lists the event as a key part of its revival plan to turnaround the airline from its poor financial situation, thereby strengthening its long-term strategies (Oneworld.com, 2014), 
as it is expected to generate a minimum of US\$25 million in annual incremental revenues (CAPA, 2014c). The advantages for Oneworld in partnering with SriLankan Airlines, is its superior international level product offering and its extensive South Asian regional presence. (CAPA, 2014b).

Sri Lanka's primary airport is Katunayake Bandaranaike International Airport, Colombo (CMB). It has been the only international airport serving the island nation up until a new airport, in South of Sri Lanka was opened in March 2013. However, the new airport has not attracted any significant passenger traffic, as Colombo handles 99.8\% (2013) of the passenger movements in Sri Lanka (ICAODATA+, 2014). Currently, 25 airlines operate at Colombo serving 41 destinations (AASL, 2014) including; British Airways, which will cease operations from 31-Mar-2014 as it will be replaced by a BA code share on SriLankan Airlines. Other Oneworld carriers will serve Colombo such as Cathay Pacific, Qatar Airways and Malaysia Airlines which will endeavour to feed connecting traffic to SriLankan Airlines at Colombo Airport which will then transport this traffic onwards to India and to the Maldives (CAPA, 2014a). In 2013, the airport handled a total of 7,311,869 passengers an increase of $3.3 \%$ from the previous year, whereas the annual capacity of the airport is only at 7 million passengers (ICAODATA+, 2014; JICA, 2012).

\section{Challenges and Prospects of Sri Lankan Aviation - Views from experts}

As a part of the study, interviews were sourced from both academic and industry experts ${ }^{1}$ from the UK and Sri Lanka. The consensus revealed that SriLankan Airlines needs to continue to formulate partnerships because of its small size in the format of increased code shares with both its Oneworld members and other carriers in order to cover more destinations 
in Europe and further expand its presence into the Americas. By selectively focusing on niche markets and by delving deeper into the Chinese territories will reap higher yield traffic and contribute to its network density as more traffic will transfer through its hub at Colombo. The experts all concurred unanimously that SriLankan Airlines are unable to compete directly with the Gulf carriers because of their sheer scale, brand presence, in-flight product superiority, and access to financial markets and airport infrastructure that encompasses their hub and spoke mechanism of moving global traffic through a single hub with just one stopover. SriLankan Airlines urgently needs to upgrade its in-flight product 'hardware' by upgrading items such as the Audio Video On-Demand (AVOD) services in all cabins, which has the possibility of using personnel iPads of which passengers are increasingly carrying on board. There is a sense of patriotism and emotional bond towards the national flag carrier and this should be extrapolated upon when reaching out to its citizens when opting to travel. Bureaucracy remains commonplace within the carrier and it needs to adopt and replicate a management structure with commercial practices similar to westernised airlines as it retains a legacy outlook. It needs to be managed by experienced business and aviation professionals which enforce commercial principles such as the termination of unprofitable routes - today's airlines need to understand what customers want and subsequently provide the expected level of service as market research is a paramount necessity in today's changing landscape. Table 3 summaries the positives and negatives relating to Sri Lanka's aviation and tourism industries as highlighted by the experts.

[INSERT TABLE 3 HERE]

\section{Data Analysis of Sri Lankan passenger traffic}


In order to demonstrate how competition has affected SriLankan Airlines' market share and revenues in a selected group of key markets, 'IATA PaxIS' data was applied to analyse the changing market dynamics between 2005 and 2013. PaxIS is a comprehensive airline passenger market intelligence database that shows the Origin and Destination traffic as well as the number of connecting passengers and the fare categories.

\section{Indian Traffic via Colombo to the Rest of the World}

India's international traffic is governed by a strict bi-lateral legislation whose market was a relatively 'closed and limited sky' for carriers from the Middle East, and Colombo acted as a 'de-facto' hub for Indian passengers as traffic rights and regulations for Sri Lanka encountered more liberalised offerings (CAPA, 2014b). However, O'Connell et al. (2013) has found that India's borders are increasingly opening to the encroaching Gulf carriers and subsequently there has been a reduction in passengers transiting via Colombo. Research shows that transiting passenger traffic on SriLankan Airlines from India to Europe and to the UAE have seen reductions of more than $70 \%$ between 2007 and 2010 as shown in Figure 4. O'Connell et al. (2013) states that this shrinkage is largely due to the fact that Emirates took advantage of the liberating skies that were being offered by the Indian Aviation authorities. However the connecting passengers from India via Colombo to Qatar, South East Asia, and more prominently Saudi Arabia have increased since the 2009-10 period. The continuous commitment to increase capacity by SriLankan Airlines to Saudi Arabia could be considered as a contributing factor for this increase as the incumbent now offers double daily flights and the Saudi market has become SriLankan Airlines third largest market. 
Subsequently the sharp drop in passengers between 2005 and 2009 triggered revenues to fall at SriLankan Airlines but the consequent strategic change to add seat capacity to Saudi Arabia and South East Asia has positively impacted its revenues by 2013 as shown in Figure 5. Further analysis indicates that the overall reduction in airfares overtime was another contributing factor towards the reduction in revenues as the average one-way fares between India and the UAE in 2005 was US\$260, while in 2013 it registered US\$192 - a drop of 26\%. Similarly in the India and Saudi Arabia market, the average one-way fares in 2005 was US $\$ 296$, dropping to US\$213 by 2013 - a fall of $28 \%$.

\section{[INSERT FIGURE 5 HERE]}

\section{United Kingdom Traffic to Sri Lanka}

The UK is the second largest tourist market for the country its importance is well defined. SriLankan Airlines' operations to the UK are solely to London Heathrow and Wickramasinghe (2014) describes the route as the 'Cash Cow' destination. Figure 6 confirms this as the Sri Lankan incumbent retains its market leadership position and transports over 160,000 passengers per annum over the last three years. The direct route is favoured by passengers and this combats the inconvenience of transiting through a Gulf hub to reach Colombo. In Apr-2013 BA re-commenced operating three weekly flights from Gatwick via Male and by its first year of operation it garnered around 20,000 passengers. However after just two years of service, BA announced that it would cease operations citing unprofitability and low passenger numbers (CAPA, 2014d). 


\section{[INSERT FIGURE 6 HERE]}

On analysing the one-way fares between the UK and Sri Lanka, it can be determined that SriLankan Airlines which has the largest market share, has continuously offered the lowest fares among its competition as outlined in Figure 7. The Fare Differential between SriLankan Airlines and Emirates is: 29\% (2005), 26\% (2007), 58\% (2010) and 41\% (2013). The lower fares are a targeted strategy in order to capture and sustain market share. The experts ${ }^{1}$ argued that the airline is compensating passengers for its poor long-haul product offerings by consistently offering lower fares, as it is not possible to match the product and service quality levels by either Emirates or Qatar Airways.

\section{[INSERT FIGURE 7 HERE]}

\section{United Arab Emirates Traffic to Sri Lanka}

SriLankan Airlines faces its stiffest competition in the UAE market as there are 47 weekly flights linking the two countries. SriLankan Airlines, Emirates, flydubai, Air Arabia, Mihin Lanka and Etihad are competing for traffic between the two nations, however SriLankan Airlines has been able to retain a leadership position transporting 130,000 passengers in 2013 as highlighted in Figure 8. It regained its dominance over Emirates in 2008 as a result of its lower fare offerings and corporate contracts to companies that supply labourers to the Gulf. 
In the recent years, the economic stimulation between the two countries have increased considerably with joint cooperation in areas of economy, trade, investment, tourism, energy and oil and gas, which has stimulated the growth of traffic overall. Trade exchange between the two countries stood at $\$ 1.5$ billion in 2012 , while the UAE investment in Sri Lanka is estimated at $\$ 440$ million (Gulf News, 2014). The results in Figure 9 show that Emirates even with its lower passenger numbers has been able to continuously gain higher revenue figures, as its huge network is able to target traffic from all around the world. It connects 142 destinations in 80 countries to Dubai - this allows it to capture traffic going to Sri Lanka from all around the world.

\author{
[INSERT FIGURE 9 HERE]
}

\title{
The findings from a passenger Survey at Colombo Airport, Sri Lanka
}

\section{General Findings}

A passenger survey was conducted from $20^{\text {th }}-21^{\text {st }}$ of June, 2014, between 09:00 and 19:00 in the departure / transit area of the International Terminal at Colombo Bandaranayke International Airport. A total of 255 passengers were approached out of which 203 provided valid responses and to-date this is the first published passenger results from a Sri Lankan aviation perspective. It has revealed many aspects of the shortcomings of SriLankan Airlines when compared to competing carriers that operate to the Island.

As majority of the respondents were travelling for leisure purposes $(83 \%)$, with the top categories being Holidays, Expats, Studying together with Visiting Friends and Relatives 
(VFR). As expected passengers travelling with Full Service Airlines (FSCs) accounted for the largest proportion of commuters at 91\%, while SriLankan Airlines accounted for 59\%, followed by Emirates (11\%) and Qatar (6\%). Passengers aged below 25 accounted for $42 \%$ of the respondents and as predicted were all travelling for leisure purposes with tickets paid for by parents. Among the older respondents (>25 years), SriLankan Airlines was more popular with $70 \%$ of them choosing the carrier, which is largely due to the legacy brand image of the airline. Sixty-four percent of the passengers travelling to short-haul destinations chose SriLankan Airlines. However for long haul travel purposes, the survey established that $51 \%$ of the respondents choose foreign airlines - the data was shared with airport research teams who indicated that the number of passengers choosing foreign carriers for long haul trips is continuously increasing, rising from $29 \%$ to $49 \%$ over recent years. This is indicative of the poor long-haul product offerings by SriLankan Airlines and the limited long-haul destinations.

\section{Purpose of Travel}

Table 4 shows the reasons why passenger are travelling and the majority of the respondents travelling for 'BUSINESS' purposes have chosen SriLankan Airlines, with urgent travellers for 'Meetings' and 'Conference' preferring the local carrier. This is largely due to superior flight connectivity and frequency especially to regional and Asian business destinations. In the 'LEISURE' category, the number of 'Residents' travelling with the Sri Lankan incumbent is exceptionally high, which shows that there is a sense of patriotism and emotional bond towards the national flag carrier. Similarly those travelling for 'Cultural' purposes have chosen SriLankan Airlines, as it operates to regional religious and cultural destinations. The number of 'Holiday' travellers' favoured foreign carriers over SriLankan Airlines as it does 
not have a sizable budget for developing its brand overseas which limits its ability to attract custom.

\section{[INSERT TABLE 4 HERE]}

\section{Booking Method}

O'Connell (2007) stated that the booking mechanism has changed from the late-90s to mid2000s, from traditional travel agents to electronic methods in most of the developed regions in Asia. The Sunday Times (2010) of Sri Lanka reported that Travel Agents generate 95\% of the business to the airlines in 2010 , but many are receiving a zero commission and thus have to charge a fee for each booking, paid for by the individual(s) who is flying. This survey reveals that majority (>63\%) of the respondents using Full Service Carriers (FSCs) continue to rely on traditional methods of booking a flight through travel agents in Sri Lanka as illustrated in Table 5. This is indicative of the slow growth of e-commerce in the country and the powerful force of travel agents.

[INSERT TABLE 5 HERE]

Reasons for selecting a carrier for leisure passengers

The results presented in Table 6 illustrate the correlation between variables set to indicate the reasoning and the respective importance when leisure passengers book a flight. A positive 
relationship was found between Service and variables including Comfort $(\mathrm{r}=0.737, \mathrm{P} \leq 0.01)$, Quality $(\mathrm{r}=0.846, \mathrm{P} \leq 0.01)$ and Fare Influence dummy $(\mathrm{FI})(\mathrm{r}=0.358, \mathrm{P} \leq 0.01)$. This implies that leisure passengers seeking a superior product are less influenced by the fare. Moreover, special Offers had a positive relationship with Fare $(r=0.313, \mathrm{P} \leq 0.01)$ and Airline Frequent Flyer Programs (FFP) $(\mathrm{r}=0.209, \mathrm{P} \leq 0.01)$. This indicates that passengers who are seeking a better fare are also interested in special Offers by airlines and benefits gained through FFPs. The relationship between Safety and variables including Fare $(r=0.378$, $\mathrm{P} \leq 0.01)$, Quality $(\mathrm{r}=0.708, \mathrm{P} \leq 0.01)$, Service $(\mathrm{r}=0.605, \mathrm{P} \leq 0.01)$, Comfort $(\mathrm{r}=0.603, \mathrm{P} \leq$ $0.01)$, Reliability $(\mathrm{r}=0.560, \mathrm{P} \leq 0.01)$. Indicates that among all other reasoning's, a high priority is also given to Safety by passengers.

[INSERT TABLE 6 HERE]

Reasons for selecting a carrier: SriLankan Airlines v All Other Full Service Carriers

Comparing between the respondents who flew on SriLankan Airlines (Figure 10) against who flew with other Full Service Carriers excluding SriLankan Airlines (Figure 11), it can be determined that 'Fare' has been the most important reason for choosing to fly with the Sri Lankan incumbent with more than $40 \%$ of the respondents choosing this category. While more than $40 \%$ of the passengers who choose to fly with foreign airlines selected 'Safety', 'Quality', 'Destinations', 'Service' and 'Comfort'. Thereby the results indicate that currently SriLankan Airlines is competing on price, whereas other carriers operating to the country appeal to passengers in a different way and place a higher value on other products rather than fare. 
[INSERT FIGURE 10 HERE]

[INSERT FIGURE 11 HERE]

Further analysis conducted through an independent sample T-test confirms that, at 95\% confidence interval, there is a distinct difference between respondents who chose another FSCs over SriLankan Airlines, considered factors such as 'Quality', 'Destinations' and 'Comfort' as shown in Table 7.

[INSERT TABLE 7 HERE]

Analysing further through the use of a one-way analysis of variance (ANOVA) evaluated the null hypothesis which concluded that there is no difference in passengers' reasoning in selecting a particular airline $(n=190)$. The analysis was carried out on each of the following attributes: Fare, Safety, Quality, Service, Comfort, Reliability, Destinations, Schedule, FFP and Special Offers, while the independent variables were set to be as; respondents travelling on SriLankan Airlines $(n=119)$, a Gulf carrier $(n=36)$ or a South East Asian carrier $(n=35)$. Thereby the assumption of homogeneity of variance was tested and it was found tenable using Levene's Test. Among the reasons of choice, the variables showed a significant difference between passengers who flew SriLankan Airlines, a South East Asian carrier or a Gulf Carrier as depicted in Table 8.

[INSERT TABLE 8 HERE]

Furthermore making comparisons between groups, the negative values obtained for the 'Mean Difference' indicate that lower rankings were given to SriLankan Airlines compared 
to Gulf and S.E Asian carriers for the respective variables shown in Table 9. For example, the average 'Service' and 'Quality' was ranked 0.9603 and 0.9680 points respectively, which are clear pointers that the Gulf carriers are viewed as offering superior products when compared to SriLankan Airlines. Thus, there is significant evidence to reject the null hypothesis and conclude that there is a significant difference in passenger's reasoning in terms of; Safety, Quality, Service, Comfort, Destinations, and FFP, for selecting a Gulf or a South East Asian carrier over SriLankan Airlines.

[INSERT TABLE 9 HERE]

\section{Conclusion}

Sri Lanka, a diverse nation, which was immersed in a bitter war for nearly three decades, is now beginning to redevelop its economy, trade and tourism portfolio. During the post war period since 2009 , tourism has played a major role in the development of the nation. Major infrastructure developments along with the opening up of previously out of bound destinations within the island has seen the tourism industry booming. International tourist arrivals have reached new peaks while the associated foreign exchange gains have continued to flourish. As a result, aviation which is the primary means of transport to the island has prospered.

Aviation in Sri Lanka is largely run by the government, holding stakes in a range of aviation related institutions including the flag carrier and the airport operator. However the industry is plagued by many shortcoming and issues, some of which are common at a global level but others are inherit to the nation. The nation's flag carrier, SriLankan Airlines dominates the industry, but faces many challenges and problems, which is evident from its 
continuous heavy losses. However government policies to uphold the tourism and aviation industries have seen the airline benefiting and subsequently growing its capacity.

Expert interviews revealed many positives, issues, challenges and prospects that both the aviation and tourism industries in the country face. Bureaucracy and inefficiency remain an embedded trait in the DNA of SriLankan Airline, while the in-flight products on the long range aircraft are inferior to its Western counterparts. It's ageing long haul fleet together along with high fuel prices, capacity constraints, and poor management practices were viewed as the major issues faced by SriLankan Airlines. The government's active involvement in its support towards the growth of the tourism industry was seen as a positive. On the other hand, uncompetitive hotel rates due to high government tax, unnecessarily high visa charges and the lack of promotion was raised as key issues for the growth of tourism. Furthermore the analysis of traffic data revealed the threats facing SriLankan Airlines by the Gulf carriers over the last number of years. The key aviation and tourism markets of India and Western Europe have been hit hard by competition; however the national carrier has been able to keep its leadership position by providing direct connections at lower fares but at the loss of reduced yields.

The passenger survey which was carried out at Colombo Airport to assess the decision making process when selecting a particular airline, revealed that the majority of the respondents were travelling for leisure purposes on SriLankan Airlines. The analysis of the booking methods revealed the extensive use of travel agents continue to dwell on the Island. Lastly in order to assess the leisure passengers reasoning for selecting a particular carrier over another, a correlation matrix was generated. This concluded that passengers influenced by Fare are more likely to look for better offers (promotions) and FFP benefits, while those passenger not influenced by Fares are seeking superior quality products. Furthermore to assess the passengers reasoning in selecting SriLankan Airlines over all other full service 
carriers the responses were cross tabulated and portrayed that SriLankan Airlines is merely competing on 'Fare', whereas other full service carriers are competing based on 'Quality', 'Destinations', 'Service' and 'Comfort'. Independent sample T-tests pointed in the same direction with high level of confidence. Additional comparisons were made between SriLankan Airlines and measured against the Gulf and the South East Asian carriers, through a one-way analysis of variance. The results painted a similar picture, indicative of the superior 'Quality', 'Service' 'Destinations' and 'Comfort' offerings of the foreign carriers, indicating that the Sri Lankan incumbent must invest in its flight products on the long haul markets in order to retain its leadership as the gateway to Sri Lanka.

\section{Endnotes}

1. Rigas Doganis - renowned aviation academic and Independent Consultant; John Strickland, Director of JLS Consulting, UK; Peter Obeysekere, Senior Partner and Managing Consultant at Aviation Consulting Group, UK; HMC Nimalsiri, Director General Civil Aviation Authority Sri Lanka; Suranga Perera, Senior Manager Qantas, (Ex-SriLankan Airlines); Thusitha Wickramasinghe, Route Management Commercial Manager (Middle East); Ruth Perera, Operations Performance Analyst British Airways; Romesh David, Director of Cinnamon Air, Sri Lanka; Darshi Piyathilaka, PhD Student of Sri Lankan Aviation at Cranfield University.

\section{References}

AASL (2014), 'Airlines at AASL' (http://www.airport.lk/flight-info/airlines-at-aasl.php, accessed 16 May 2014). CAPA (2014a), 'Colombo Bandaranayke International Airport' (http://centreforaviation.com/profiles/airports/colombo-bandaranayake-international-airport-cmb, accessed 5 July 2014).

CAPA (2014b), 'SriLankan Airlines raises global profile and expands oneworld presence in South Asia' (http://centreforaviation.com/analysis/srilankan-airlines-raises-global-profile-and-expands-oneworldpresence-in-south-asia-166654, accessed 8 May 2014).

CAPA (2014c), 'SriLankan Airlines turnaround hinges on fleet renewal, yield improvements and oneworld' (http://centreforaviation.com/analysis/srilankan-airlines-turnaround-hinges-on-fleet-renewal-yieldimprovements-and-oneworld-167181, accessed 10 May 2014). 
CAPA (2014d), 'British Airways to suspend London Gatwick-Male-Colombo service from 29 Mar 2015' (http://centreforaviation.com/news/british-airways-to-suspend-london-gatwick-male-colombo-service-from29-mar-2015-378153, accessed 1 September 2014).

Cassim, N. (2013), 'CEO confident of SriLankan Airlines' route to profitability' (http://www.ft.lk/2013/12/30/ceo-confident-of-srilankan-airlines-route-to-profitability/, accessed 2 May 2014).

CIA (2013), 'The World Fact Book' (https://www.cia.gov/library/publications/the-world-factbook/geos/ce.html, accessed 20 November 2014).

Department of Census and Statistics - Sri Lanka (2012), 'Census of Population and Housing - 2012' (http://www.statistics.gov.lk/PopHouSat/CPH2012Visualization/htdocs/index.php?usecase=indicator\&actio n=Map\&indId=11, accessed 16 May 2014).

Department of Census and Statistics, Sri Lanka (2014), 'Annual Summery Indicators - 2013', Department of Census and Statistics, Sri Lanka, Colombo.

Doganis, R. (2010), Flying Off Course, 4th Ed, Routledge, Oxon, United Kingdom.

Flightglobal (2014), 'SriLankan Airlines' (http://dashboard.flightglobal.com/app/profiles/\#/airline/summary/228, accessed 20 May 2014).

Gulf News (2014), UAE-Sri Lanka Joint Committee holds first meeting in Abu Dhabi, $26^{\text {th }}$ January, accessed at http://gulfnews.com/business/economy/uae-sri-lanka-joint-committee-holds-first-meeting-in-abu-dhabi1.1282554, accessed 29 May, 2014).

Heritage Foundation, T. (2014), 'China Global Investment Tracker' (http://www.heritage.org/research/projects/china-global-investment-tracker-interactive-map, accessed 1 July 2014).

IATA ' (2014), 'IATA Fact Sheet: Fuel, IATA, Montreal,' (https://www.iata.org/pressroom/facts_figures/fact_sheets/Documents/fuel-fact-sheet.pdf, accessed 5 July 2014).

ICAODATA+ (2014), 'ICAODATA+', (https://stats.icao.int/FGLogin, accessed 22 May 2014).

JICA (2012), 'Signing of ODA Loan Agreements with the Democratic Socialist Republic of Sri Lanka' (http://www.jica.go.jp/english/news/press/2011/120328.html, accessed 8 June 2014).

Ministry of Finance and Planning (2013), 'Ministry of Finance Annual Report 2013' (http://www.treasury.gov.lk/publications/under-fiscal-management-responsibility-act/annual-reports/26national-planning/fiscal-policy/580-annual-report-2013-chapters.html, accessed 16 May 2014).

O'Connell, J. F., Krishnamurthy, P., Warnock-Smith, D., Lei, Z. and Miyoshi, C., (2013), 'An investigation into the core underlying problems of India's airlines', Transport Policy, Vol. 29, No. 0, pp 160-169.

O' Connell, J., F. (2007), 'The strategic response of full service airlines to the low cost carrier threat and the perception of passengers to each type of carrier'. $\mathrm{PhD}$ thesis. Cranfield University.

OAG (2014), 'Schedules Analyser' (http://analytics.oag.com/home/, accessed 06 August 2014).

Ondaatjie, A. (2014), 'Growing China Ties Let Sri Lanka Rebuff U.S. War Inquiry Push' (http://www.bloomberg.com/news/2014-03-06/growing-china-ties-let-sri-lanka-rebuff-u-s-war-inquirypush.html, accessed 11 June 2014).

Oneworld.com (2014), 'SriLankan Airlines joins oneworld' (http://www.oneworld.com/newsinformation/oneworldnews/-/asset_publisher/QtTQ7EuCzxhd/content/srilankan-airlines-joins-oneworld/, accessed 25 May 2014).

Perovic, J. (2013), 'The Economic Benefits of Aviation and Performance in the Travel \& Tourism Competitiveness Index, in Travel and Tourism Competitiveness Report 2013, World Economic Forum, Geneva' (http://www3.weforum.org/docs/TTCR/2013/TTCR_Chapter1.4_2013.pdf, pp. 57, accessed 10 July 2014).

Rajapaksha, M. (2005), 'Mahinda Chinthana', 1st Ed, Colombo (www.president.gov.lk/pdfs/MahindaChinthanaEnglish.pdf, accessed 13 June 2014).

SLTDA (2012), 'Flyer', SLDTA, Colombo (http://www.sltda.lk/sites/default/files/Flyer\%202012.pdf, accessed 15 May 2014).

SLTDA (2014a), ‘Annual Reports’ (http://sltda.lk/annual_reports, accessed 18 May 2014).

SLTDA (2014b), 'Hotels - \& Other Accommodation' (http://www.srilanka.travel/index.php?route=travel/tostay\&hotel_type=19\&hotel_district=, accessed 19 June 2014).

SriLankan Airlines (2013), 'SriLankan Airlines Annual Report 2012-13', SriLankan Airlines, Colombo (http://www.srilankan.com/corporate/pdf/annualreport/SriLankan_Airlines_Annual_Report_2012_2013.PDF, accessed 10 May 2014).

SriLankan.com (2014), 'SriLankan Airlines to join oneworld on 1 May' (http://www.srilankan.com/corporate/en_uk/home/news-details/153, accessed 5 May 2014). 
Subasinghe, D. R. (1985), 'Now a Sri Lankan Free Market Economic Miracle' (http://www.heritage.org/research/reports/1985/05/now-a-sri-lankan-free-market-economic-miracle, accessed 8 May 2014).

Sunday Times (2010) IATA BSP scheme suffocates Sri Lankan Travel Agents, (http://www.sundaytimes.lk/100627/ BusinessTimes/bt20.html, accessed 24 June, 2014).
UNdata
(2014),
'UNdata
Country
Profile
Sri
Lanka' (https://data.un.org/CountryProfile.aspx?crName=SRI\%20LANKA, accessed 6 May 2014).

Wickramasinghe, T. (2014), Manager Commercial Route Management (Middle East), author interview at SriLankan Headquarters, Colombo, June.

Wijedasa, N. (2014) "Hotel construction explodes", The Sunday Times, (News), 06/08, pp. 16.

World Travel and Tourism Council Data (2013), 'Sri Lanka - Travel \& Tourism Direct Contribution to GDP Travel \& Tourism Direct Contribution to GDP - \% share' (http://knoema.com/atlas/SriLanka/topics/Tourism/Travel-and-Tourism-Direct-Contribution-to-GDP/Direct-Contribution-to-GDPpercent-share, accessed 10 June 2014) 


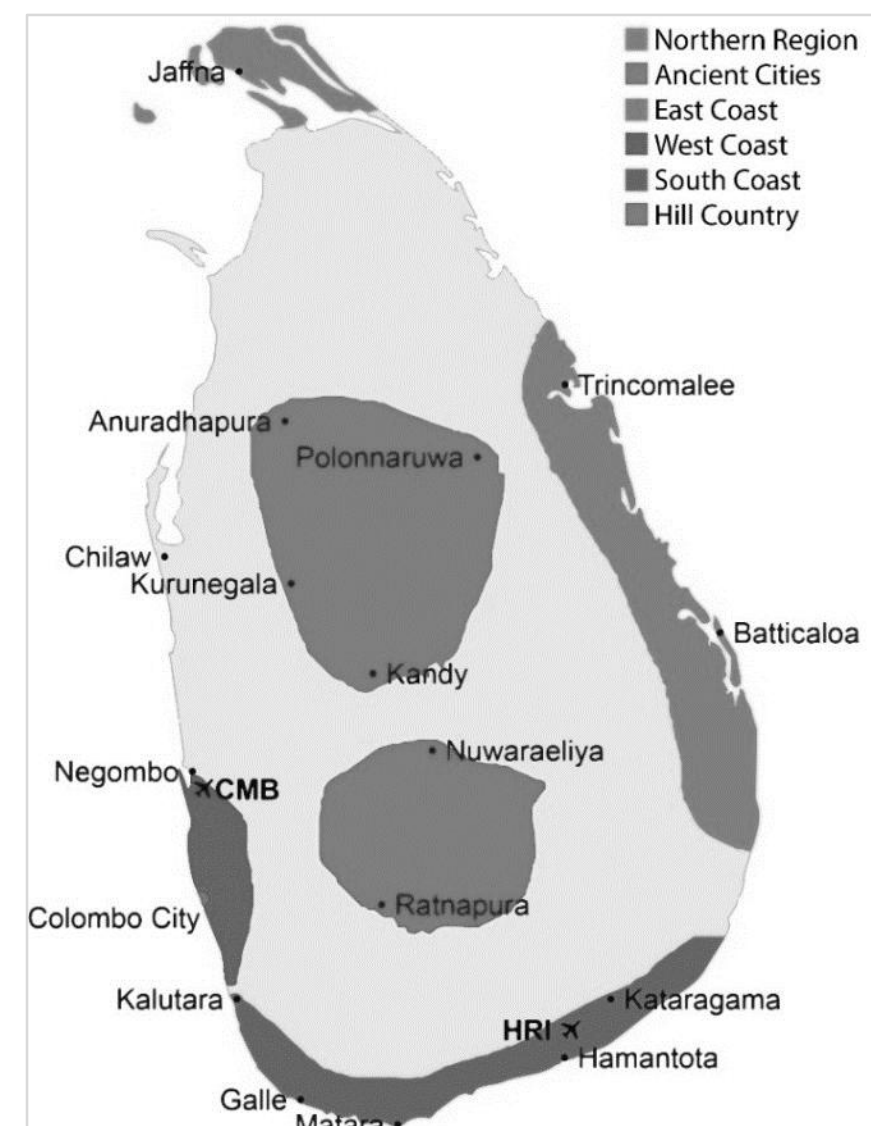

Figure 1. Resort Regions and Cities of Sri Lanka. Source: SLTDA, 2012 


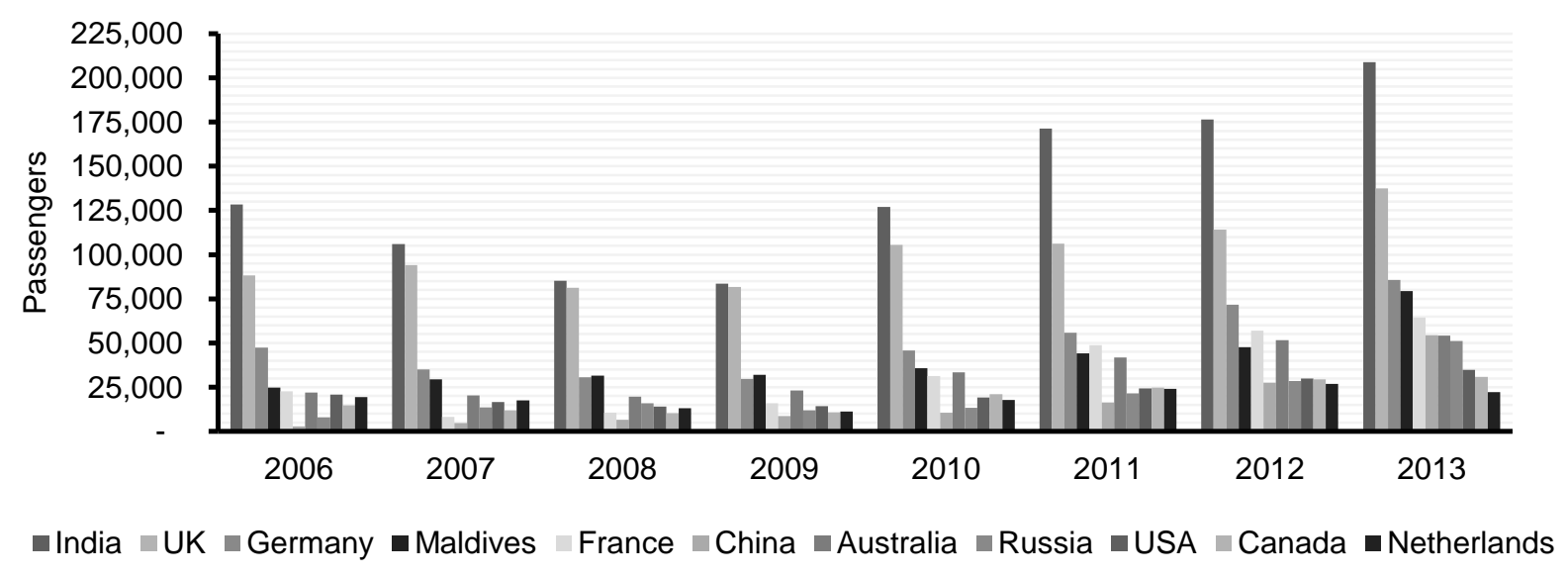

Figure 2. Tourist Arrivals to Sri Lanka by Country (Top 10).

Source: SLTDA, 2014a 


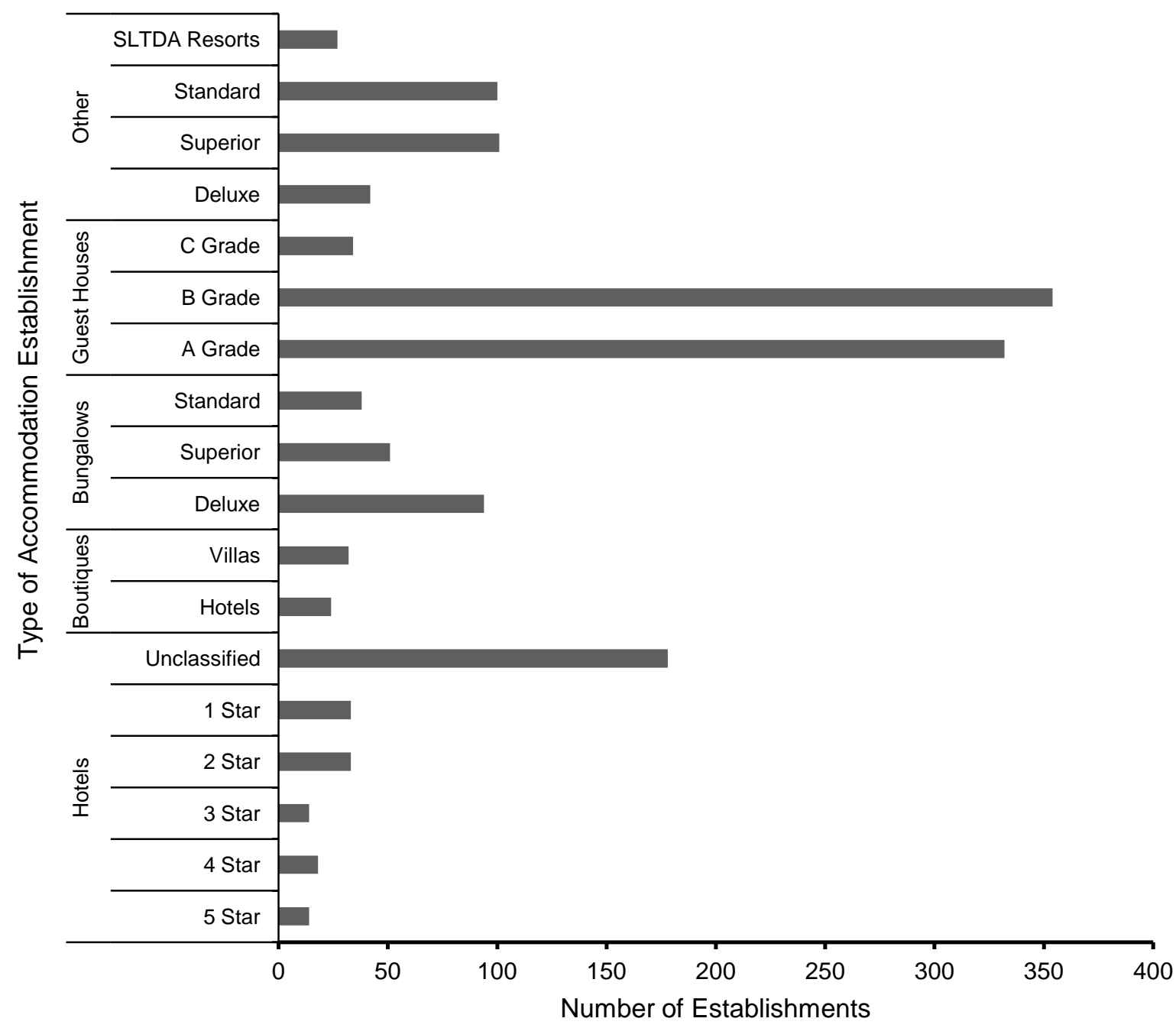

Figure 3. Tourist Accommodation Establishments (as at June-2014) Source: SLTDA, 2014a 


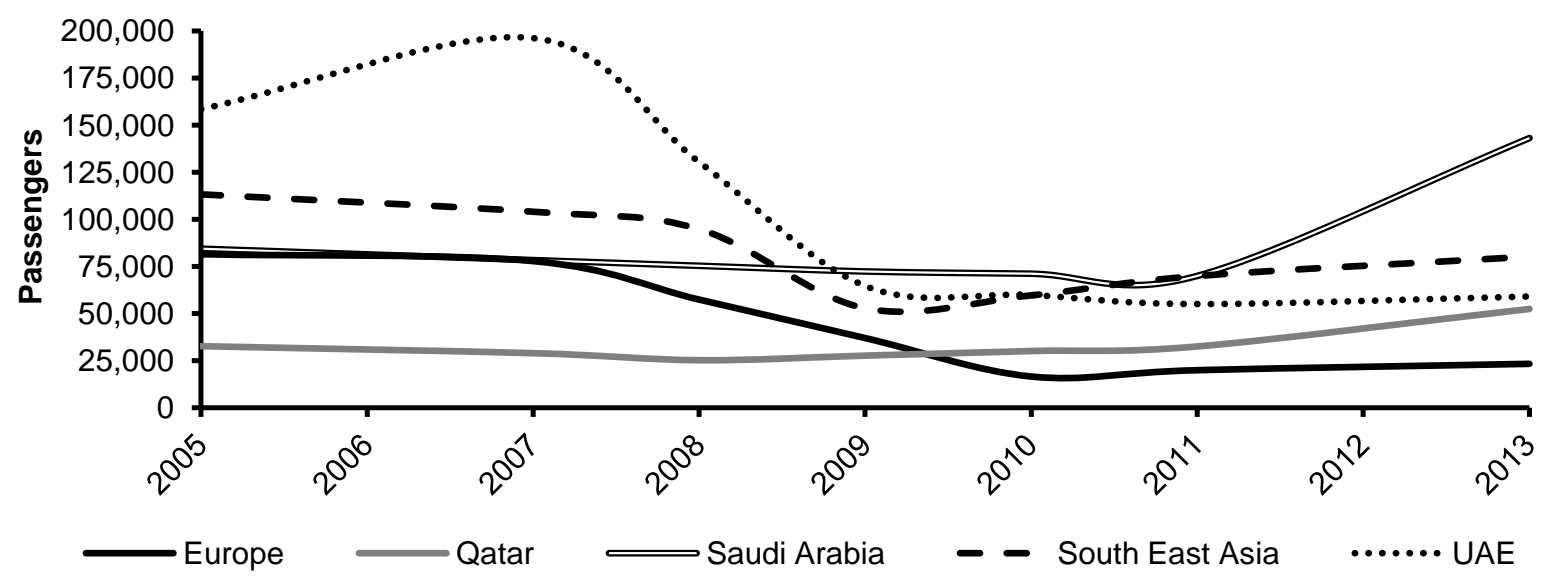

Figure 4. Indian Transit Traffic via Colombo on SriLankan Airlines - Passengers Source: IATA PaxIS 


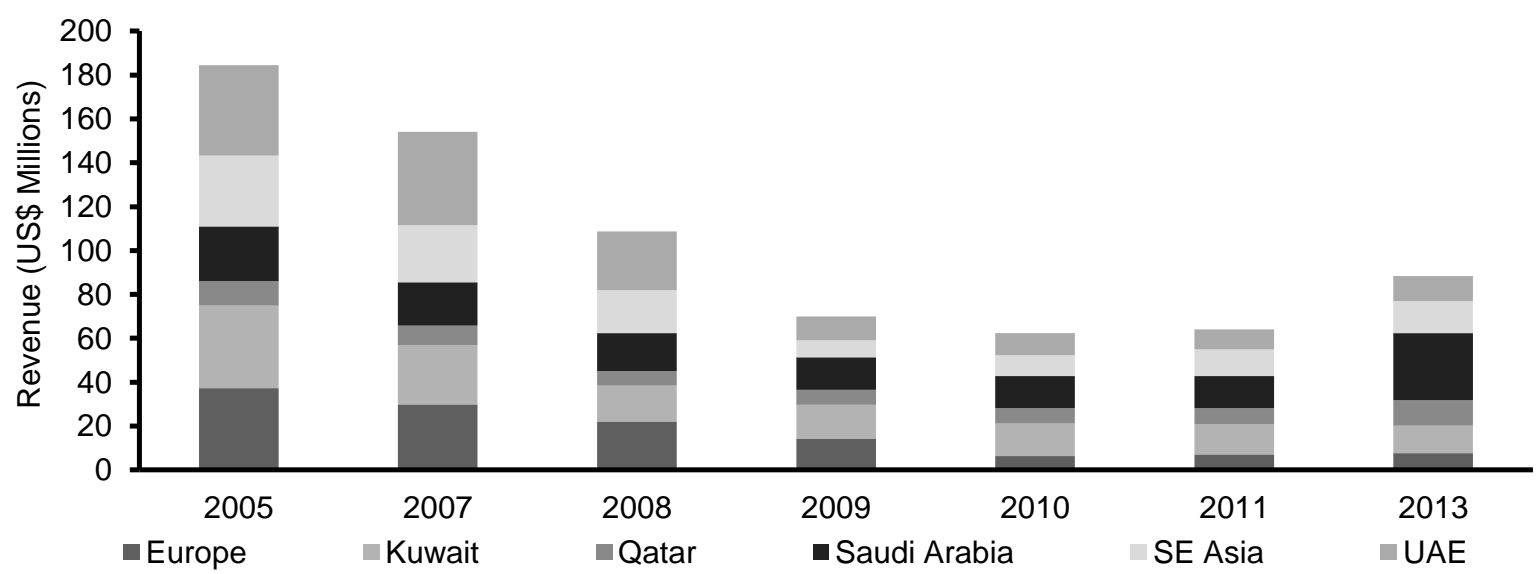

Figure 5. Indian Transit Traffic via Colombo on SriLankan Airlines - Revenues Source: IATA PaxIS 


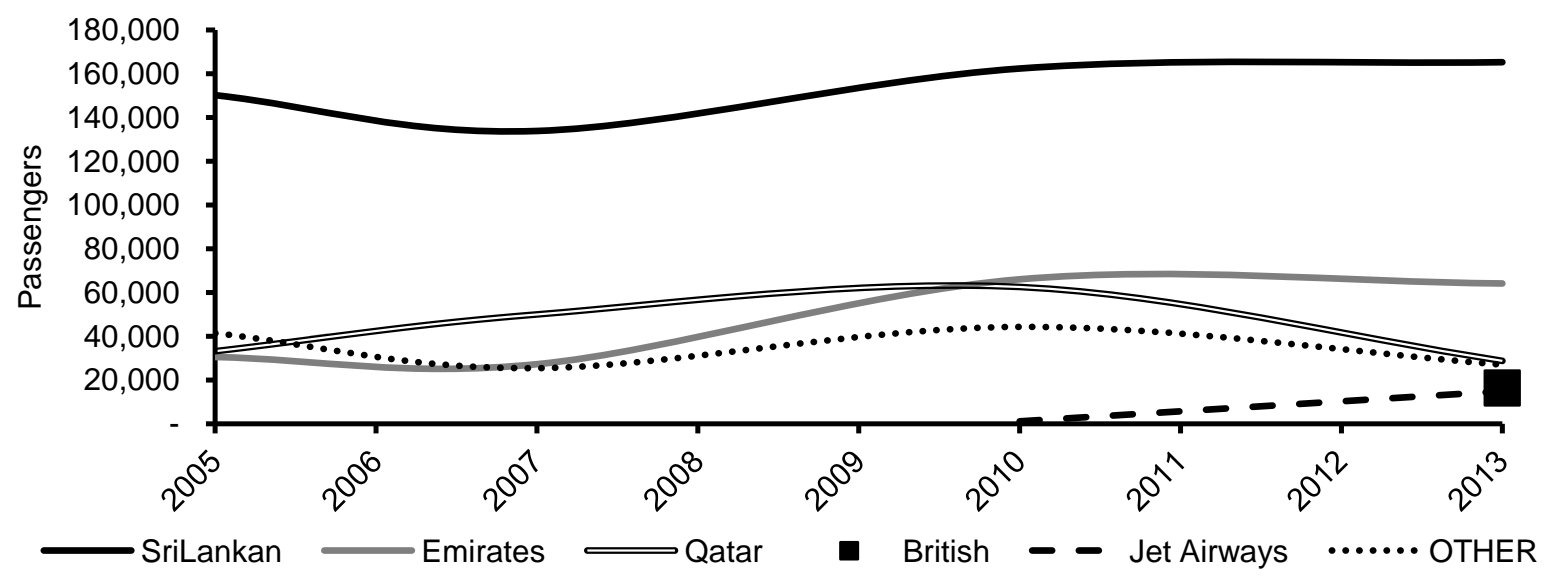

Figure 6. UK Traffic to Sri Lanka - Passengers

Source: IATA PaxIS 


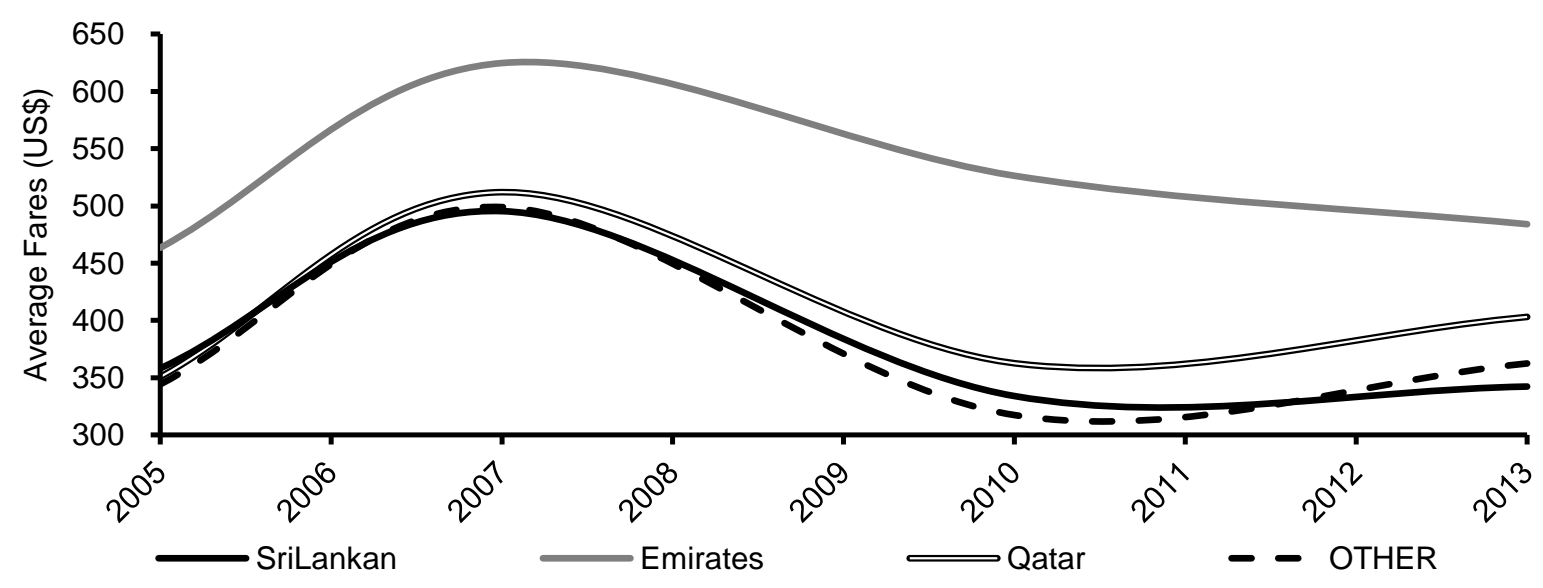

Figure 7. UK Traffic to Sri Lanka - Average One-Way Fares Source: IATA PaxIS 


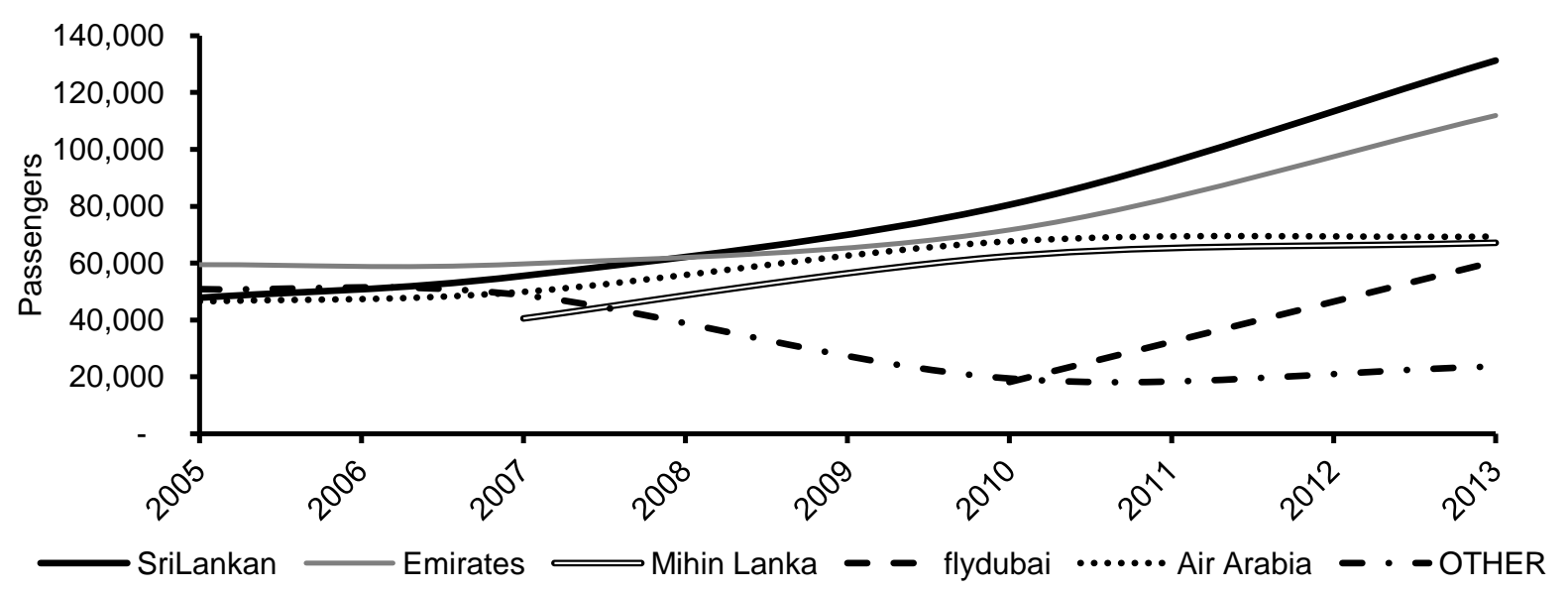

Figure 8. UAE Traffic to Sri Lanka - Passengers

Note: Etihad's market share between Abu Dhabi and Colombo accounts for only a minor proportion, so therefore it is included in 'Other'

Source: IATA PaxIS 


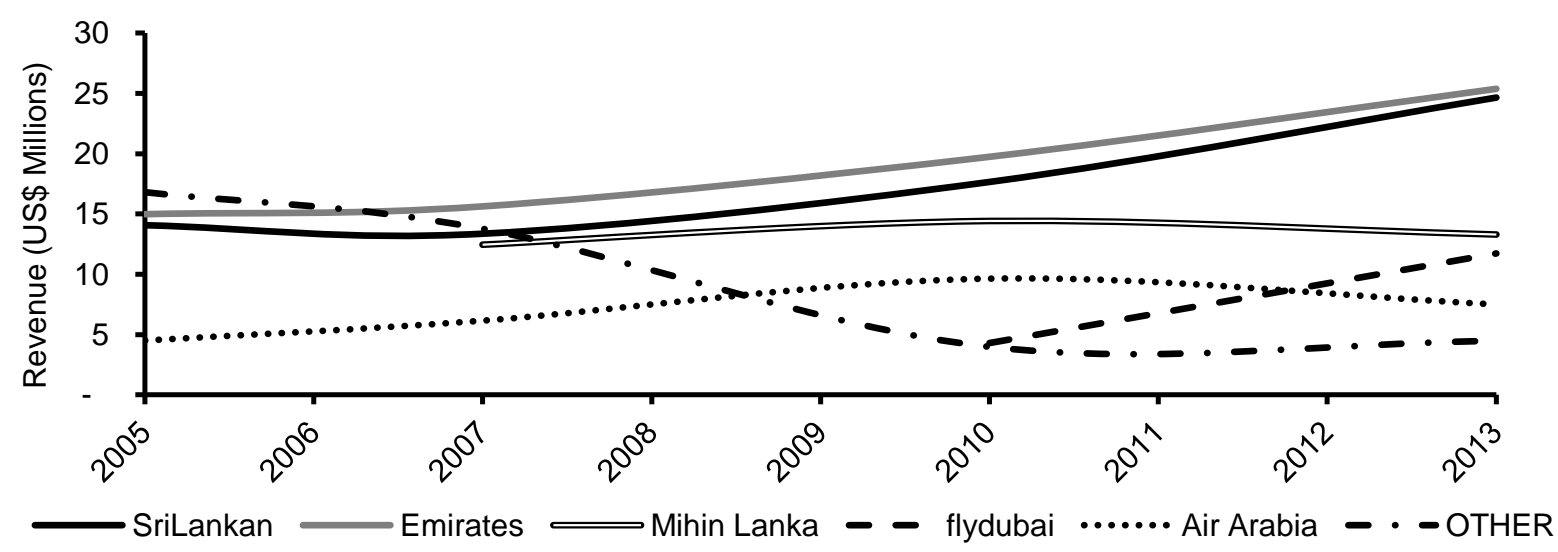

Figure 9. UAE Traffic to Sri Lanka - Revenues

Source: IATA PaxIS 


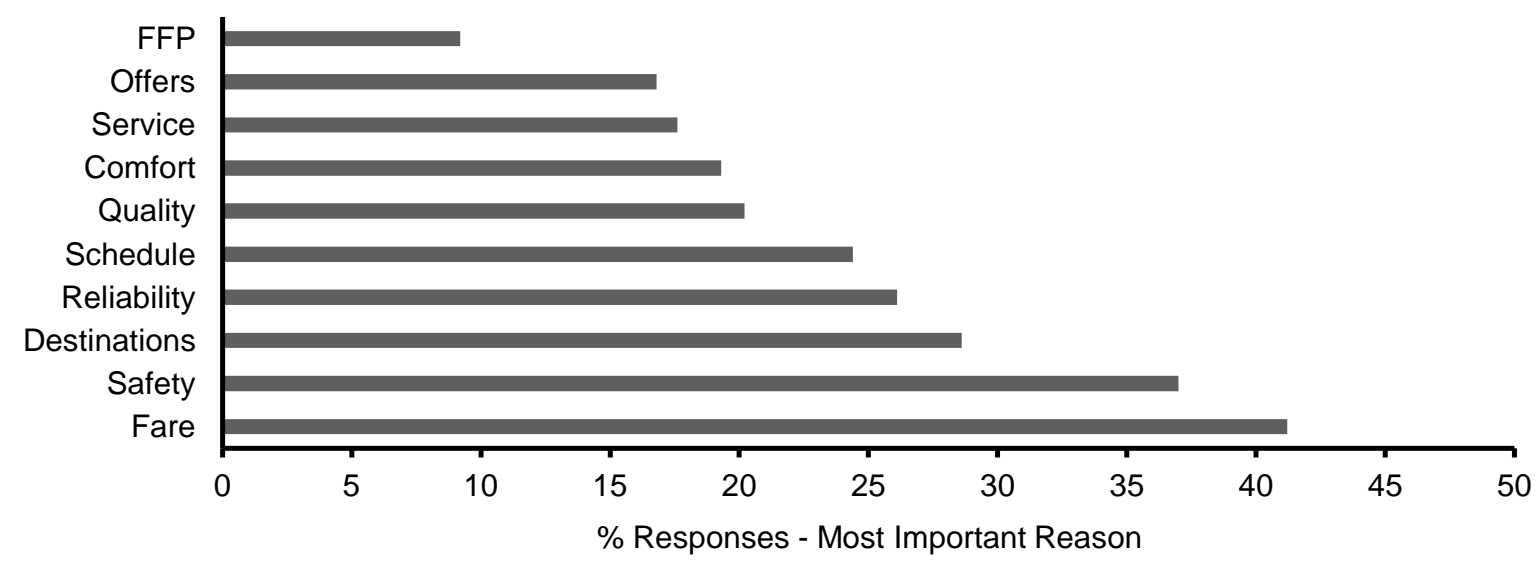

Note: A Likert Ranking system was applied (1: Least Important to 5: Most Important)

Figure 10. Percentage Responses - Most Important Reason (Respondents flying SriLankan Airlines only) $(\mathrm{n}=119)$ 


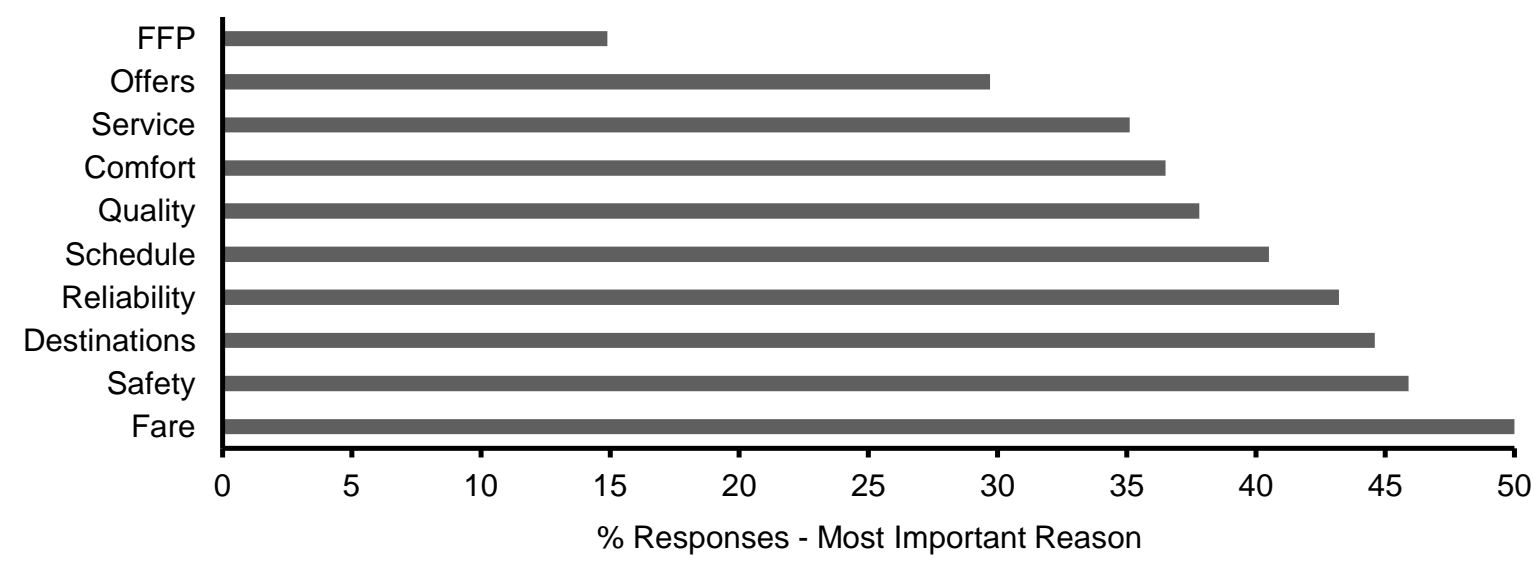

Note: A Likert Ranking system was applied (1: Least Important to 5: Most Important)

Figure 11. Percentage Responses - Most Important Reason (Respondents flying all Full Service Airlines excluding SriLankan Airlines) $(\mathrm{n}=74)$ 
Table 1. Aircraft Utilisation Benchmark.

\begin{tabular}{|c|c|c|c|c|c|}
\hline \multirow{2}{*}{ Airline } & \multicolumn{2}{|c|}{ Narrow-Body } & \multicolumn{2}{|c|}{ Wide-Body } & \multirow{2}{*}{$\begin{array}{c}\text { Overall } \\
\text { Average Hours }\end{array}$} \\
\hline & Aircraft & Average Hours & Aircraft & Average Hours & \\
\hline UL & 9 & 12.2 & 13 & 12.4 & 12.3 \\
\hline $\mathrm{QR}$ & 47 & 11.9 & 76 & 16.1 & 14.5 \\
\hline BA & 106 & 11.5 & 146 & 12.4 & 12.0 \\
\hline $9 \mathrm{~W}$ & 61 & 12.4 & 22 & 8.3 & 11.3 \\
\hline
\end{tabular}

Note: UL, SriLankan Airlines; QR, Qatar Airways; BA, British Airways; 9W, Jet Airways. Source: OAG, 2014 
Table 2. Airline Staff Key Performance Indicator Comparison.

\begin{tabular}{lccc} 
Airline & Total Staff & Staff/ Aircraft & Cost/ Staff Member US\$ \\
UL & 5,900 & 289 & 16,465 \\
9W & 14,000 & 177 & 20,990 \\
BA & 39,000 & 146 & 143,060 \\
SQ & 14,000 & 134 & 156,740 \\
\hline
\end{tabular}

Source: Flightglobal, 2014 
Table 3. Positives and negatives of Sri Lanka's aviation and tourism industries

\section{Positives}

Customer relations

Oneworld alliance

Cheap labour

5 Year turnaround plan

Short-haul product

Regional brand value

Engineering expertise

New airport in the South (HRI)

Training facilities

Rapid tourism growth post-2009

Government support

Infrastructure developments

\section{Negatives}

\section{SriLankan Airlines and Aviation}

Management (politically endorsed)

Financial Results

Fuel tax

Aircraft financing

Weak hub and spoke structure

Inferior long-haul product

Unprofitable routes

Political and Diplomatic Strategies based routes

$85 \%$ rural population

Capacity Constraints

\section{Tourism Industry}

Uncompetitive product offerings

28\% Hotel tax

Policy mismatch between Tourism and

Aviation

Negative International publicity

Visa charges

Source: Expert Interviews 
Table 4. Purpose of Travel.

SriLankan Airlines

$\%$

11.9

BUSINESS

Meeting

Conference

Employment

Trade fair

Training

LEISURE

Resident

Holiday

VFR

Studying

Cultural

Sports

Honeymoon

Shopping
3.1

3.1

2.6

2.6

0.5

49.8

20.3

10.4

7.3

6.7

3.1

1.0

0.5

0.5

\section{All Other FSCs}

$\%$

5.7

2.1

1.6

0.5

0.5

1.0

32.6

2.6

15.0

3.6

7.8

0.5

1.0

0.5

1.6
Standard Deviation

0.516

0.447

0.500

0.408

0.577

0.321

0.497

0.483

0.508

0.378

0.577

0.707

0.500

TOTAL

61.7

38.3

$100 \%$ 
Table 5. Booking Method.

\begin{tabular}{clccc}
\multicolumn{2}{c}{ Booking Method } & $\begin{array}{c}\text { SriLankan Airlines } \\
\text { \% }\end{array}$ & $\begin{array}{c}\text { All Other FSCs } \\
\%\end{array}$ & $\begin{array}{c}\text { Other LCCs } \\
\%\end{array}$ \\
\multirow{2}{*}{ Traditional } \\
Methods & Travel Agent & 52.1 & 61.3 & 40.0 \\
& Airline Office & 10.1 & 4.0 & - \\
& Call Centre & 1.7 & - & - \\
Electronic & Airline Website & 19.3 & 13.3 & 50.0 \\
Methods & Other Website & 3.4 & 4.0 & - \\
& Mobile App & - & 1.3 & - \\
& Family Booked & 10.9 & 5.3 & - \\
\hline \multirow{2}{*}{ Other } & Office Booked & 2.5 & 9.3 & - \\
& Other & - & 1.3 & 10.0 \\
\hline
\end{tabular}




\begin{tabular}{|c|c|c|c|c|c|c|c|c|c|c|c|}
\hline $1 \mathrm{FI}$ & 1 & & & & & & & & & & \\
\hline 3 Safety & $0.189^{*}$ & $0.378^{* *}$ & 1 & & & & & & & & \\
\hline 4 Quality & $0.327^{* *}$ & $0.172^{*}$ & $0.708^{* *}$ & 1 & & & & & & & \\
\hline 5 Service & $0.358^{* *}$ & 0.118 & $0.605^{* *}$ & $0.846^{* *}$ & 1 & & & & & & \\
\hline 8 Destinations & 0.008 & 0.119 & $0.270^{* *}$ & $0.292^{* *}$ & $0.289 * *$ & $0.192^{*}$ & $0.273^{* *}$ & 1 & & & \\
\hline 9 Schedule & 0.057 & $0.153^{*}$ & $0.190^{*}$ & $0.250 * *$ & $0.244^{* *}$ & $0.238^{* *}$ & $0.211^{* *}$ & $0.493^{* *}$ & 1 & & \\
\hline 10 FFP & 0.093 & 0.141 & $0.262^{* *}$ & $0.272^{* *}$ & $0.223^{* *}$ & $0.267^{* *}$ & $0.229^{* *}$ & $0.213^{* *}$ & $0.263^{* *}$ & 1 & \\
\hline 11 Special Offers & 0.016 & $0.313^{* *}$ & $0.188^{*}$ & $0.220^{* *}$ & 0.146 & $0.168^{*}$ & 0.068 & $0.156^{*}$ & 0.141 & $0.209^{* *}$ & 1 \\
\hline
\end{tabular}


Table 7. SriLankan Airlines v Other FSCs - independent samples T-test.

\begin{tabular}{lccc}
\hline Reason & $\mathbf{t}$ & Degrees of Freedom & Significance (2-tailed) \\
Quality & -4.994 & 191 & 0.000 \\
Comfort & -4.566 & 191 & 0.000 \\
Destinations & -3.656 & 191 & 0.000 \\
Reliability & -3.263 & 191 & 0.001 \\
Schedule & -2.944 & 191 & 0.004 \\
Special Offers & -2.476 & 191 & 0.014 \\
Safety & -2.362 & 191 & 0.019 \\
FFP & -2.125 & 191 & 0.035 \\
\hline
\end{tabular}


Table 8. Test of Homogeneity of Variances.

\begin{tabular}{lcccc}
\hline Reason & Levene Statistic & Df1 & Df2 & Significance \\
Fare & 1.214 & 3 & 199 & 0.306 \\
Safety & 0.846 & 3 & 199 & 0.470 \\
Reliability & 2.292 & 3 & 199 & 0.079 \\
Destinations & 2.548 & 3 & 199 & 0.057 \\
Schedule & 1.548 & 3 & 199 & 0.203 \\
FFP & 1.216 & 3 & 199 & 0.305 \\
Special Offers & 0.623 & 3 & 199 & 0.601 \\
\hline
\end{tabular}

Note: Middle Eastern carriers include: Emirates, Qatar Airways, Etihad Airways and Oman Air. South East Asian carriers include: Malaysia Airlines, Thai Airways, Singapore Airlines and Air Asia X 


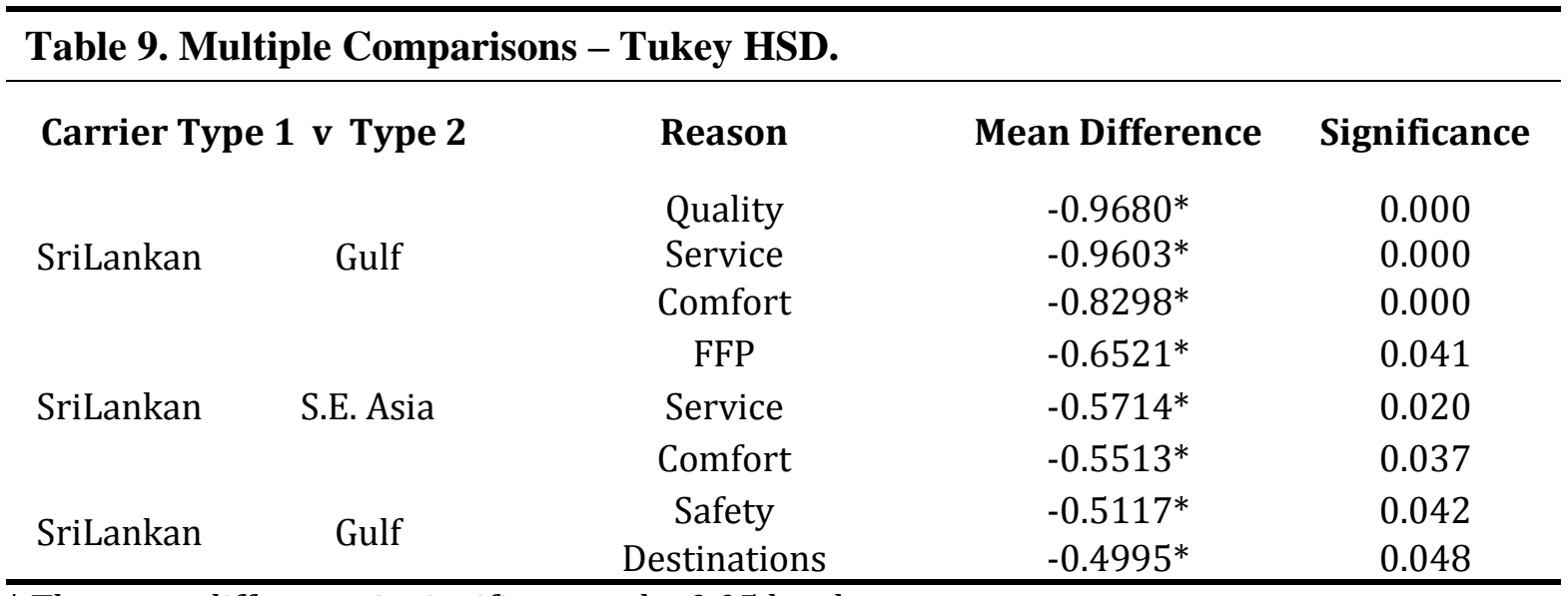

* The mean difference is significant at the 0.05 level. 


\section{An analysis of the issues and prospects facing SriLankan Airlines and its embedded partnership with Sri Lankan tourism}

Nagahawatte, L.

IP Publishing

Nagahawatte L, O'Connell JF, An analysis of the issues and prospects facing SriLankan Airlines and its embedded partnership with Sri Lankan tourism, Tourism economics, Tourism Economics October 2016 vol. 22 no. 5 908-927.

http://dx.doi.org/10.5367/te.2015.0465

Downloaded from Cranfield Library Services E-Repository 